\title{
TÂNĂRUL CREŞTIN ŞI PATIMA DESFRÂNĂRII ÎN SOCIETATEA SECULARIZATĂ
}

Nicolae Aloman*

Abstract: The Christian Youth and the Lasciviousness in the Secularized Society. In the modern society the young person who wants to preserve his or her chastity and live a moral life according to God's will is going to find this very difficult to achieve. This mission becomes even more challenging as we notice that the modern world has already reached unprecedented levels of moral corruption. Today, when the Christian world is struggling, when modernism with its open_invitation to unlimited material comfort invades every corner of our life, when cohabitation, infidelity and sexual perversions suffocate more and more young people and sensuality is highly preferred over the purity of the true love, the teachings of the Holy Gospels and those of the Holy Fathers become the safest support for the young person who wants to live an authentic moral life in a secularized society. At the same time God, Who is forgiving and merciful, offers the young person who is possessed by lasciviousness the opportunity to correct him or herself and, through the works of the Holy Sacraments, provides them with additional means to straighten out many things in society and live a life according to God's precepts.

The pure love is the one that extends the life of Christ into our earthly life, for in each and every pure body there is a holy temple of God, meaning that pure young person becomes the altar where Christ is willing to bring Himself as a pleasing offering to God the Father.

Keywords: young, lasciviousness, sexuality, marriage, sacraments.

\section{Introducere}

Vremurile pe care le trăim sunt marcate de o continuă răzvrătire împotriva ordinii oficial instituite a lumii. Clasica explicaţie şi motivare a acestei răzvrătiri este năzuinţa spiritului

*PhD Candidate, Faculty of Orthodox Theology at "1 December 1918" University, Alba Iulia, Romania. 
uman spre un ideal de viaţă mai înalt, iar aspectul negativ al răzvrătirii este coborârea adepţilor ei într-un mod de viaţă îndepărtat de principiile morale.

Chiar dacă păcate şi fărădelegi s-au comis frecvent de-a lungul istoriei, oamenii erau conştienţi că greşesc. Opinia publică, comunitatea din care făceau parte şi chiar conştiinţa morală sancţionau abaterile de la viaţa normală. Din păcate, astăzi, s-a ajuns să nu se mai facă deosebire între bine şi rău, iar relaţiile extraconjugale, convieţuirea în uniune consensuală, întemeierea unui cuplu cu o persoană de acelaşi sex, precum şi atât de comuniunea trupească înainte de căsătorie devin lucruri normale pentru o lume anormală. Întrebarea pe care ar trebui să ne-o punem cu toţii este: Cum putem trăi frumos într-o astfel de lume? Pare o misiune imposibilă, intangibilă. Cu toate acestea, avem menirea de a încerca din răsputeri acest lucru şi să-i determinăm şi pe ceilalţi tineri să o facă. Generaţia de tineri e încătuşată în această disperare, deoarece unii dintre ei văd prea bine că lumea e distrusă şi se îndreaptă spre un sfârşit. Trebuie să fim conştienţi însă că răul nu există ca principiu ontologic, ci apare în mod secundar, prin părăsirea binelui. Dar părăsirea binelui presupune liber arbitru sau voie liberă. Şi doar fiindcă există fiinţe cu libertate de alegere, devine posibilă părăsirea binelui şi apariţia răului, căci în afara liberei alegeri, nu există rău, de sine stătător. Aşadar, răul, deşi inexistent prin sine însuşi, îşi dobândeşte existenţă în fiinţele cu libertate de alegere, care părăsesc binele.

Pentru a duce o viaţă morală exemplară, întâi de toate trebuie să gândim frumos. Trebuie să gândim frumos, pentru că toate faptele îşi au izvorul în cugetare, iar cel care are idei frumoase şi sănătoase, de bună seamă va acţiona corect. Fiecare om este dotat cu un potenţial de participare la Ideea de Frumos. Din păcate, sunt mulţi care au simţul frumosului pervertit; aşa ne explicăm dezacordurile şi contestaţiile care o însoţesc permanent, dar care nu prejudiciază 


\section{$15^{\text {th }}$ International Symposium on Science, Theology and Arts}

unicitatea Frumuseţii ${ }^{1}$. Dumnezeu le-a făcut pe toate bune foarte (Fc. 1,31). Nu le-a înfăţişat dintru început ca desăvârşite, ci l-a chemat pe om la lucrare şi la purtare de grijă, spre împlinirea scopului final al creaţiei Lui. Pe de altă parte, noţiunea de bine sau însuşirea făpturilor de a fi bune nu se mărgineşte aici doar la frumusețea lor, ci se judecă după rostul creaţiei ${ }^{2}$. Dar şi frumuseţea făpturilor dă la iveală frumuseţea Creatorului, care este frumuseţea cea mai presus de fiinţă, care transmite frumuseţe tuturor fiinţelor ${ }^{3}$.

În orice discurs, prelegere, lucrare sau teză este necesară stăpânirea proprietăţii termenilor. Prin urmare, pe parcursul lucrării vom întâlni termeni precum, eros, agape, concupiscenţă, care nefiind uzuali s-ar putea să nu fie întru totul accesibili, fapt pentru care voi schiţa câteva repere în elucidarea lor. Vom întâlni deseori cuvântul erotism, care îşi are rădăcina în grecescul eros, semnificând acel aspect al iubirii care se manifestă printr-o puternică dorinţă sexuală. Aşadar, sexualitatea este considerată ca fiind legată atât de instinctele umane primare (pofte), cât şi de cele mai înalte (eros). Doar cu ajutorul harului, sexualitatea umană poate transforma eros-ul într-o iubire jertfelnică, agape. Aşa cum patima reprezintă pervertirea a tot ceea ce este bun, tot aşa şi agape reprezintă desăvârşirea a tot ceea ce este bun ${ }^{4}$. Cuvântul concupiscenţă desemnează acel amestec de sentimente şi de senzaţii care stăpâneşte pe cineva atunci când plăcerea sexuală stă deasupra raţiunii. În acest sens, plăcerea poate fi calificată drept cauză a tuturor păcatelor, după prototipul oricărui păcat, cel al primilor noştri părinţi (Fac. 3, 6). Plăcerea nu e

${ }^{1}$ Georges Habra, Iubire şi senzualitate, traducere de Dora Mezdrea, Bucureşti, Edit. Anastasia, 1994, p. 72.

2 Sfântul Vasile cel Mare, Omilii la Hexaemeron, în Sfântul Vasile cel Mare, „Scrieri”, partea întâi, traducere, introducere, indici și note de Dumitru Fecioru, colecţia „Părinți și Scriitori Bisericești”, vol. 17, Bucureşti, Edit. Institutului Biblic şi de Misiune al Bisericii Ortodoxe Române, 1986, p. 117.

${ }^{3}$ Georgios Mantzaridis, Morala creştină, trad. de Cornel Constantin Coman, Bucureşti, Edit. Bizantină, 2006, p. 13.

${ }^{4}$ William Basil Zion, Eros şi Transfigurare, traducere de Ioan Ovidiu Bobăilă, Alba Iulia, Edit. Reîntregirea, 2001, p. 265. 
obligatoriu să fie trupească, din moment ce există unele plăceri care nu implică preponderenţa trupului, cum ar fi pizma, orgoliul sau ipocrizia $^{5}$.

În prezenta lucrare vom încerca să desluşim cauzele care duc la pervertirea morală a tinerilor şi posibilul tratament tămăduitor, pentru ca, la rândul lor, să-i poată apăra pe alţi tineri de a mai trece prin astfel de experienţe. Adolescenţa este o perioadă a provocărilor, în timpul căreia tânărul are de făcut alegeri importante, alegeri pentru care este responsabil, în virtutea maturităţii sale; trebuie să aleagă între ideal şi imoral, între bine şi rău, între Dumnezeu şi diavol, între creştinism şi orice altceva. În adolescenţă, omul trăieşte suspansul întrebărilor, iar răspunsurile pe care le alege devin principii de viaţă după care el se ghidează şi acţionează.

\section{Caracterul grav al desfrâului}

Legătura bărbatului cu femeia prin căsătorie este instituită de către Dumnezeu odată cu crearea primei perechi de oameni, Adam şi Eva. Prin această legătură, soţii devin un trup şi preînchipuie legătura dintre Hristos şi Biserică. În Noul Testament, această legătură instituită şi binecuvântată de Dumnezeu este ridicată la rangul de Taină.

Numai în cadrul căsătoriei este permisă legătura trupească dintre bărbat şi femeie, pentru ca prin aceasta să se poată înmulţi neamul omenesc şi evita desfrânarea. Orice altă legătură trupească dintre bărbat şi femeie este oprită. Porunca aceasta opreşte nu numai desfrânarea săvârşită în trup, ci şi desfrânarea în cuget, gând, ori pofte şi dorinţe desfrânate, căci Mântuitorul a spus: Eu vă zic vouă că oricine caută la femeie spre a o pofti, a şi desfrânat cu ea în inima sa (Mt. 5, 28)

\footnotetext{
${ }^{5}$ Georges Habra, op. cit., p. 189-190.

${ }^{6}$ Nicolae Mladin, Orest Bucevschi, Constantin Pavel, Ioan Zăgrean, Teologia Morală Ortodoxă, manual pentru Facultăţile de Teologie, vol. I, Alba Iulia, Edit. Reîntregirea, 2003, p. 132-133.
} 
Vocaţia trupului este aceea de a reuni la un loc duhul cu lutul, în aşa fel încât cel din urmă să se alăture căii ascendente a celui dintâi. Iată un aspect pe care nu trebuie să-1 uităm nicio clipă: omul este suflet, dar are şi un trup, după cum ne aminteşte şi Sfântul Vasile cel Mare:

„Dacă am fi alcătuiţi numai din suflet, ne-am înţelege unii cu alţii numai prin gândire; dar, pentru că sufletul nostru îşi zămisleşte gândul ascuns în trup ca sub o perdea, este nevoie de verbe şi de nume ca să facem cunoscute cele aflate în adâncul nostru"”.

Prin urmare, Sfântul Vasile cel Mare conchide că noi suntem duh şi minte, întrucât am fost făcuţi după chipul şi asemănarea Creatorului; ale noastre sunt trupul şi simţurile din el. Facultăţile sufletului sunt raţiunea şi instinctul, care, la rândul lui, se divide în dorinţă şi mânie. În paralel cu instinctul vieţii, există un alt instinct, anume atracţia unui sex către celălalt, care apare ca o mişcare involuntară ce apare la orice ființă normală. Pe de altă parte însă, cu totul izolat şi separat de acesta, şi câteodată chiar ca o respingere hotărâtă a impulsului sexual, se manifestă erosul, freamătul iubirii şi căutarea de contopire cu persoana iubită. Atât erosul, cât şi impulsul sexual, apar în mod egal, ca manifestări ale sexualităţii; însă bifurcarea, despărţirea lor, câteodată chiar antagonismul dintre ele face să se înţeleagă că sexualitatea, în om, este ceva complex: o putere spiritual-corporală $\breve{8}^{8}$.

Când acest instinct este pervertit, intervine desfrâul, de care Sfântul Apostol Pavel ne îndeamnă să fugim, pentru că orice păcat $l$ ar face omul este în afară de trup; cel ce se dă însă desfrânării

\footnotetext{
${ }^{7}$ Sfântul Vasile cel Mare, Omilia a III- $a$, în Sfântul Vasile cel Mare, „Omilii și cuvântări”, traducere din limba greacă şi introducere de Dumitru Fecioru, text revăzut şi notă asupra ediţiei de Dumitru Fecioru, Constantin Georgescu şi Alexandru Mihăilă, colecţia „Părinți și Scriitori Bisericești”, serie nouă, vol. 1, Bucureşti, Edit. Basilica a Patriarhiei Române, 2009, p. 70.

${ }^{8}$ Vasily Vasilyevich Zenkovsky, Convorbiri cu tinerii despre sexualitate, traducere de Dimitrie Balaur, Bucureşti, Edit. Bizantină, 2006, p. 26.
} 
păcătuieşte în însuşi trupul său (I Cor. 6, 18). Mai înainte de orice, desfrâul este o trădare a iubirii curate. Din punct de vedere spiritual şi tainic, avem de-a face cu dărâmarea unui templu. E o abatere nesăbuită de la un plan al providenţei divine. Un amestec nepermis şi iresponsabil într-o ordine voită de Dumnezeu. Desfrânarea nu se referă numai la săvârşirea faptei impudice şi ilicite dinainte de căsătorie, ci mai ales la cea din vremea căsătoriei, când primeşte denumirea de adulter. Totuşi, desfrânarea se deosebeşte de adulter, căci deşi este un act nelegiuit, ca şi adulterul de altfel, are loc între două persoane libere de angajamentul căsătoriei ${ }^{9}$. În viaţa intimă înainte de căsătorie, în afară de principiile în ce priveşte sănătatea, desfrâul aduce cu el un adevărat şoc, care zdruncină din temelii buna rânduială a firii întregi. Calea curăţiei, calea abstinenţei până la căsătorie, este dictată nu numai de cerinţele moralei, de acea poruncă care spune categoric: Să nu desfrânezi!, ci şi de natura însăşi a iubirii, inspirate de eul nostru etnic, care într-un fel este legea internă a vieţii noastre intime (sexuale) ${ }^{10}$.

Oricât de de grave ar fi greşelile din cadrul vieţii sexuale, săvârşite din uşurătatea minţii, din nesocotinţă sau sub influenţa altora, acestea nu trebuie socotite ca ireparabile. De multe ori întâlnim tineri care, făcând o greşeală în ceea ce priveşte viaţa normală sexuală, au ajuns, în disperarea lor, la concluzia ca pentru ei, calea curăţiei este închisă pentru totdeauna. Modul acesta de a gândi este o adâncă şi foarte păgubitoare rătăcire, întrucât la sfârşitul lumii Dumnezeu le va şterge toate lacrimile din ochi (Apoc. 7, 7).

O importantă cauză a relaţiilor extraconjugale ar putea fi şi vârsta fragedă la care numeroşi tineri îşi încep viaţa sexuală. Numeroase studii arată o strânsă legătură între debutul precoce al relaţiilor intime şi raporturile extramaritale de mai târziu ${ }^{11}$. De

${ }^{9}$ Ilie Moldovan, Adolescenţa, preludiu la poemul iubirii curate, ediţia a treia, Alba Iulia, Edit. Reîntregirea, 2014, p. 184.

${ }^{10}$ Ibidem, p. 156.

${ }^{11}$ Sandfort T., Sexual practices and their social profiles, în Hubert MC, Bajos N., and Sandfort T. (editors), Sexual Behaviour and HIV/AIDS in Europe: Comparisons of National Surveys, London, University College, London Press, 
asemenea, o implicaţie negativă a relaţiile extraconjugale constă în faptul că acestea favorizează răspândirea bolilor cu transmitere sexuală. Este alarmant acest lucru. Şi nu doar ortodocşii sancţionează caracterul grav al desfrâului, ci şi cei de alte confesiuni. Chiar şi adepţii unor grupări neoprotestante din America de Sud împărtăşesc convingerea că viaţa ar trebui concentrată în jurul religiei, iar comportamentul care contravine ordinii morale rânduite de Dumnezeu trebuie respins cu orice preţ ${ }^{12}$.

Din nefericire, opinia propagată prin toate mijloacele de comunicare este pentru păcat. La diferite emisiuni, anumite persoane preocupate de diminuarea bolilor cu transmitere sexuală nu îi sfătuiesc pe tineri sa ducă o viaţă morală, ci să desfrâneze protejat. De asemenea, prietenii povestesc cu pasiune aventurile lor păcătoase, iar mijloacele de comunicare în masă promovează păcatul. Chiar şi în spaţiul publicitar sau în marketing a fost instaurată dezordinea morală, prin tacticile subversive de a capta atenţia consumatorilor. Una din aceste tactici populare foloseşte imagini sexuale explicite în publicitate, chiar şi atunci când imaginea sexuală are puţină relevanţă pentru produsul promovat. Se observă în mod evident încălcarea normelor etice prin impunerea forţată a sexului gratuit în publicitate $^{13}$.

1998, p. 106-164; Bozon M., Reaching adult sexuality: first intercourse and its implications, în Bozon M., and Leridon H. (editors), Sexuality and the Social Sciences: A French Survey on Sexual Behaviour, Aldershot, LK: Dartmouth, 1996, p. 143-175; Michael T., The Number of Partners, în Laumann E. O. (ed.), Social Organization of Sexuality: Sexual Practices in the United States, Chicago, IL, USA, University of Chicago Press, 1994, p. 174-224; White R., Cleland J., and Carael M., Links between premarital sexual behaviour and extramarital intercourse: a multi-site analysis, AIDS, 2000, 14 (15), p. 23232331

${ }^{12}$ Zelee E. Hill, John Cleland, and Mohamed M. Ali, Religious Affiliation and Extramarital Sex among Men in Brazil, în "International Family Planning Perspectives", vol. 30, Nr. 1, Martie 2004, p. 20.

13 Darren W. Dahl, Jaideep Sengupta, and Kathleen D. Vohs, Sex in Advertising: Gender Differences and the Role of Relationship Commitment, în "Journal of Consumer Research", vol. 36, Nr. 2, August 2009, p. 215-216. 
Revenind la eroismul tânărului care se străduieşte să ducă o viaţă morală, în duhul Evangheliei, amintim că păcatul desfrânării este în strânsă legătură şi cu alte păcate, unele mult mai profunde şi, prin urmare, mai puţin vizibile, dar care, toate, se îmbină într-un cerc vicios. Amintim în sensul acesta egoismul, egocentrismul; tânărul se iubeşte pe sine, doreşte să obţină plăcere pentru sine; este capabil să-i distrugă sufleteşte, moral, pe alţii, pentru a-şi satisface dorinţele trupeşti ${ }^{14}$. În al doilea rând putem vorbi despre eroarea prin care tânărul ajunge să creadă că materia poate da viaţă şi fericire. În această greşeală a căzut şi Adam. Nu trebuie să ne limitatăm simţurile şi emoţiile la nivelul materiei şi, de asemenea, nu trebuie să gândim că fericirea şi mulţumirea stau în cele văzute, materiale, ci mai degrabă în Fiul lui Dumnezeu, Cuvântul, care acordă viaţă şi este scopul vieţii. De asemenea, putem vorbi şi de singurătate, care de cele mai multe ori îl împinge pe tânăr în păcatul desfrâului; acolo îşi găseşte el refugiul ${ }^{15}$. Toţi însă vor spune că un tânăr frumos şi sănătos e nefiresc să nu aibă relaţii sexuale. Castitatea, virtute creştină, e luată în derâdere ${ }^{16}$. După cum aminteam la început, anormalul devine normal, ajungând la o criză a valorilor, în care virtuţi precum fidelitatea, castitatea, rugăciunea, smerenia sunt respinse, uitate sau catalogate drept relicve ale trecutului ${ }^{17}$.

\section{Perversiunile sexuale}

Faptul că lumea este supusă erotismului nu mai este o noutate pentru nimeni. Ştirile zilnice sau cotidienele prezintă exagerat de des violuri, incesturi şi alte numeroase imoralităţi. Toate aceste

\footnotetext{
${ }^{14}$ Bishop Moussa, Youth and pure love, în Fr. Markos R. Hanna, Moral Issues: The Church's View Point on Contemporary Issues, United States of America, Xlibris Corporation, 2012, p. 83.

${ }^{15}$ Ibidem, p. 83-84.

${ }^{16}$ Andrei Andreicuţ, Mai putem trăi frumos? Pledoarie pentru o viaţă morală curată, Cluj-Napoca, Edit. Renaşterea, 2012, p. 43-44.

${ }^{17}$ Teofil Tia, Un (im)posibil dialog duhovnicesc al erei post-moderne, Alba Iulia, Edit. Reîntregirea, 2010, p. 4.
} 
perversiuni sexuale provin din exacerbarea viciului şi extinderea lui, până când ajunge să spargă cadrele naturale. Comentând cuvintele Sfântului Apostol Pavel (Rom. 1, 26-27) despre cea mai caracteristică dintre perversiuni - homosexualitatea, Sfântul Ioan Hrisostom spune: Vezi cum intreaga lor dorinţă vine din nesaț, care nu suportă să stea în hotarele lui ? Şi tot ceea ce incalcă legile stabilite de Dumnezeu pofteşte alte lucruri decât cele leginite ${ }^{18}$. Această perversiune nu este aproape niciodată de origine ereditară şi nici măcar organică, ci în mod esenţial psihică. Înseamnă, de fapt, supravieţuirea în adult a unor elemente, chiar dacă elaborate şi rafinate, ale unor tendinţe sexuale infantile ${ }^{19}$.

Dumnezeu a poruncit, la început, perechii umane (bărbat şi femeie): Creşteţi şi vă înmulţiţi (Fac. 1, 28). Actele sodomice provoacă dezgust, dispreţ, repulsie. Sunt nişte caricaturi, contrafaceri, surogate ale sexualităţii fireşti. Din cauza vieţii sexuale intense, precum şi diverselor forme neigienice şi bizare de practicare a actului sexual, homosexualitatea poate fi un vector pentru numeroase boli virale, parazitare, bacteriene şi fungice. Menţionăm că SIDA a devenit epidemică şi din pricina homosexualităţii, prin homosexualii bisexuali şi prin cei consumatori de substanţe narcotice $^{20}$.

Îndepărtându-se de învăţătura Bisericii, o seamă de cercuri liberale creştine fac eforturi pentru legitimizarea homosexualităţii. Problema trebuie examinată cu multă seriozitate, întrucât în mediul ortodox există o mare reţinere, dar şi o confuzie universală în această problemă, referitoare, pe de o parte, la homosexualitate ca stare, şi pe de altă parte, la viciul homosexual. Zion consemnează în „Eros şi transfigurare": Este important ca preoţii ortodocşi şi laicii să fie conştienţi de motivele pentru care actele homosexuale trebuie

18 Sfântul Ioan Gură de Aur, Comentariile sau explicarea Epistolei către Romani, Omilia V, traducere de Theodosie Athanasiu, Bucureşti, Atelierele grafice Socec \& Co, 1906, p. 52.

19 Teofil Tia, Culisele psihice ale sexualităţii, Alba Iulia, Edit. Reîntregirea, 2010-2011, p. 8.

${ }^{20}$ Irineu Pop, Curs de Bioetică, Cluj-Napoca, Edit. Renaşterea, 2005, p. 84-85. 
respinse ca imorale. In acest domeniu isteria nu ajută nimănui şi duce la anxietate şi nedreptate ${ }^{21}$.

Fetişismul este concentrarea exagerată a apetitului sexual asupra unei anumite părţi a obiectului sexual, în aşa fel încât obiectul şi celelalte părţi ale lui sunt lăsate deoparte. Această perversiune demonstrează în mod clar lipsa de maturitate psiho-afectivă a celui stăpânit de ea. Aceşti indivizi trebuie trataţi cu multă grijă pastorală, precauţie şi compasiune, întrucât ei trebuie să evolueze constant spre o maturizare psiho-afectivă ${ }^{22}$.

Sadismul şi masochismul sunt perversiuni pe cât de frecvente, pe atât de mediatizate. Sadismul, în sens restrâns, constă în a încerca o plăcere de ordin sexual din a tiraniza şi violenta obiectul iubit. Cruzimea sadicului poate ajunge până la asasinat. Perechea sadismului este masochismul; el constă în a încerca plăcerea de ordin sexual din suportarea tiraniei şi a violenţei. Masochismul nu trebuie confundat cu anihilarea eului, care este perechea exaltării justificate a obiectului iubit; anihilarea este proprie iubirii celei mai curate, din moment ce Însuşi Fiul lui Dumnezeu $S$-a dezbrăcat de Sine Însuşi (Filip. 2, 7), atenuând splendoarea slavei Sale dumnezeieşti, dânduŞi viaţa pentru a-1 înălţa pe $\mathrm{om}^{23}$. Sadicul este în acelaşi timp masochist, şi viceversa.

Exhibiţionismul şi voyeurisme-ul desemnează o dublă perversiune, care constă în a găsi satisfacţie sexuală, cel dintâi, în a se arăta gol, în aşa fel încât să determine obiectul iubit să procedeze la fel (perversiune predilect masculină), iar cea de-a doua, în care plăcerea sexuală derivă din observarea sau studierea atitudinilor erotice ale altor persoane.

Auto-erotismul masturbatoriu desemnează o poluţie provocată fără să-i corespundă vreun conţinut. Este vorba, deci, de un act reflex şi fizic, a cărui efecte sunt nefaste, secătuind sistemul

\footnotetext{
${ }^{21}$ William Basil Zion, op cit., p. 236.

${ }^{22}$ Ibidem, p. 21.

${ }^{23}$ Georges Habra, op. cit., p. 263.
} 
nervos, inducând o stare adâncă de deprimare, iar în cazul femeilor, după teoria lui Freud, ajungându-se la frigiditate ${ }^{24}$.

Pe lângă aceste perversiuni, există încă o multitudine (pedofilia, incestul, zoofilia, etc.), care au o frecvenţă imensă în lumea actuală despre care spuneam că e supusă erotismului. Neruşinarea este atât de mare, încât nu doar că se etalează la lumina zilei, dar cere şi drept de cetate (de pildă, prostituţia, care nu se mulţumeşte să fie tolerată legal, ci vrea să fie considerată o muncă ca oricare alta). Preoţi de toate confesiunile apără la televiziune dreptul a doi bărbaţi să se căsătorească între ei. Medici şi directori de conştiinţă cutează să recomande masturbarea ca pe un factor de emancipare al individului. Cărţile marchizului de Sade şi ale lui Sacher Masoch cunosc o răspândire incredibilă. Unele reviste publică oferte sadice şi masochiste foarte precise şi detaliate. Crimele de un sadism atroce proliferează neliniştitor şi copiii sunt victimele preferate; căci cu inocența şi neputinţa de a se apăra, copilul este ţinta preferată a sadicilor ${ }^{25}$.

Cercetările psihologice evidenţiază faptul că perverşii prezintă întotdeauna un $e u$ slab, pasiv, fără iniţiativă, cu lipsă de simţ a realităţii, cu scăzute sentimente de culpă, adeseori insuficient conştienţi de perversiunile lor, care nu sunt fructul unor opţiuni voluntare. Şi revenim cu lait-motivul nostru: cum putem trăi frumos într-o astfel de lume?

\footnotetext{
${ }^{24}$ Ibidem, p. 266.

${ }^{25}$ Ibidem, p. 267.
} 


\section{Taina iubirii}

Deşi a fost creată bună de către Dumnezeu, sexualitatea umană, după căderea omului în păcat, şi-a pierdut coerenţa care a existat în Paradis între bărbat şi femeie. Ca o consecinţă, patimile, prin pierderea finalităţii raţionale, s-au dezlănţuit într-un război împotriva sufletului. Omul a înlocuit iubirea cu desfrâul. Transformarea patimilor este prima sarcină a mântuirii. Ascetismul se constituie ca un prim pas în această direcţie, dar numai prin transformarea sa în iubire, condiţia umană îşi poate recăpăta asemănarea cu Dumnezeu ${ }^{26}$.

Niciunul dintre marii gânditori sau dintre poeţi $n$-a aflat vreodată răspuns la întrebarea: ce este iubirea?. Îi putem urma evoluţia, dar nu putem spune nimic despre naşterea ei. Cert este că iubirea există din veşnicie: iubirea dintre Tatăl suprem şi Fiul, care ni se descoperă în cea mai înaltă iubire, fără început şi fără sfârşit şi care se îndreaptă spre cea de a treia Persoană a Sfintei Treimi, Sfântul Duh ${ }^{27}$. Dacă o formulă a iubirii ar fi posibilă, s-ar putea afla însăşi formula omului. Marele Miracol este că Dumnezeu a făcut doi dintr-unul şi că aceștia doi rămân unul singur ${ }^{28}$. Adam şi Eva, deşi erau doi, rămân unul, adică îşi regăsesc şi îşi reconstituie adevărul lor iniţial, tainic. Aceeaşi o idee o întâlnim şi la Shakespeare în „Phoenix şi Turturica” sau la Dostoievski în „Adolescentul”, unde fiinţa iubită este numită viaţă vie.

Unul din scopurile sexualităţii este procrearea, dar nu este principalul, ci unirea a două persoane, adică integrarea dorinţei, a atracţiei şi a comuniunii personale într-un singur trup, unirea trupească intermediind comuniunea persoanelor. În contextul

\footnotetext{
${ }^{26}$ William Basil Zion, op. cit., p. 265.

${ }^{27}$ Dumitru Stăniloae, Sfânta Treime sau la început a fost iubirea, București, Edit. Institutului Biblic şi de Misiune al Bisericii Ortodoxe Române, 2005, p. 68.

${ }^{28}$ Paul Evdokimov, Taina iubirii. Sfinţenia unirii conjugale în lumina tradiţiei ortodoxe, trad. de Gabriela Moldoveanu, Bucureşti, Edit. Christiana, 1994, p. 137.
} 


\section{$15^{\text {th }}$ International Symposium on Science, Theology and Arts}

revelaţiei creştine, iubirea dintre bărbat şi femeie devine o Taină, atunci când este înălţată la unirea dintre Hristos şi Biserica Sa. Arhetipul lui Hristos, Care-şi iubeşte Biserica (trupul şi mireasa Lui), este temelia legăturii sacramentale. Temeiurile căsătoriei, întâlnite atât în creaţie, cât şi în înălţarea ei de către Hristos, sunt argumente solide pentru căsătoria creştină ${ }^{29}$. Incredinţarea de acest adevăr este un prim pas în trăirea unei vieţi morale autentice într-o lume preponderent impregnată de erotism accentuat şi desfrâu. Procrearea joacă un rol esenţial în definirea şi semnificaţia căsătoriei ca instituţie. Având în vedere faptul că multe dintre beneficiile societăţii se datorează căsătoriei, acesta ar trebui să constituie un real semnal de alarmă pentru tinerii vremurilor pe care le trăim, care minimalizează sau banalizează importanţa acestei Taine ${ }^{30}$.

Unirea bărbatului şi a femeii creează o comuniune de iubire harică, prin care se oglindeşte, în în mod tainic, chipul Sfintei Treimi. Rezultatul unirii aduce la viaţă o a treia persoană, şi astfel se întemeiază mica Biserică (Sfântul Ioan Hrisostom), adică familia, o imagine a Treimii ${ }^{31}$.

Un alt motiv al instituirii Tainei Căsătoriei este micşorarea poftelor neînfrânate. Stă mărturie Sfântul Apostol Pavel, când zice: Din pricina desfrânării, fiecare bărbat să aibă soția sa (I Cor. 7, 9). În altă parte, tot el spune: Pentru aceste două motive a fost lăsată căsătoria: ca să ne păstrăm curăţia şi ca să devenim părinţi. Sfântul Ioan Gură de Aur, în tratatul său „Despre feciorie”, spune:

„Bună este căsătoria, pentru că-1 face pe om să păzească curăţia şi nu-1 lasă să cadă în desfrânare şi să moară. Nu defăima, deci, căsătoria! Este de mare folos, nu lasă ca mădularele lui Hristos să ajungă mădularele

\footnotetext{
${ }^{29}$ William Basil Zion, op. cit., p.266.

${ }^{30}$ James V. Brownson, Bible, gender, sexuality: a critical engagement, The Kirby Laing Institute for Christian Ethics, 2014, p. 35.

${ }^{31}$ William Basil Zion, op. cit., p. 266.
} 
unei desfrânate şi nici nu îngăduie ca templul cel sfânt să ajungă pângărit şi necurat" ${ }^{, 32}$.

Mai cităm în acest sens un duhovnic rus modern, pe nume Alexander Elchaninov:

„Doar prin căsătorie oamenii se pot cunoaşte deplin unul pe celălalt; miracolul de a simţi, de a atinge, de a vedea personalitatea celuilalt este la fel de minunat şi de singular ca şi cunoaşterea lui Dumnezeu de către mistic. De aceea, putem zice că omul, înainte de căsătorie pătrunde în profunzimile ei, prin intermediul personalităţii altcuiva. Bucuria cunoaşterii reale şi a vieţii reale ne dă sentimentul de plenitudine şi de satisfacere prin intermediul căruia suntem mai bogaţi şi mai înţelepţi”’33.

Taina iubirii, cu toată puterea ei, a fost din păcate dată uitării. Plăcerea şi durerea au devenit strâns legate. Doar printr-o viaţă nouă în Hristos, sclavia plăcerii şi a durerii este biruită. Cu toate acestea, capacitatea eros-ului de a atrage şi a aduce împreună este forţa principală în interiorul vieţii şi experienţei umane. Astfel de forţe rămân oarbe dacă nu sunt testate de realitate. Eros-ul devine agape în măsura în care caracterul deosebit al celuilalt, cu toate particularităţile lui sau ale ei, este afirmat. Această deosebire se transformă în înstrăinare dacă se rezumă doar la afirmarea voinţei celuilalt, şi nu are în vedere libertatea şi bunătatea celuilalt, aşa cum sunt ele percepute. Eros-ul reprezintă o modalitate de a fi împreună, dar în cazul în care deosebirea nu este afirmată, atracţia se transformă în încercarea de a-1 poseda sau chiar de a fi celălalt (idee preponderent narcisistă). Diferenţierea trebuie să fie exprimată, altfel eros-ul devine o posesivitate sufocantă. Dialogul se află în inima

${ }^{32}$ Sfântul Ioan Gură de Aur, Despre feciorie, traducere de Dumitru Fecioru, Bucureşti, Edit. Institutului Biblic şi de Misiune al Bisericii Ortodoxe Române, 2001, p. 23.

${ }^{33}$ Alexander Elchaninov, Credinţa vine din iubire, traducere de Boris Buzilă, Bucureşti, Edit. Sophia, 2005, p. 67. 
iubirii autentice, şi acesta se poartă în limbajul afecţiunii, dobândindu-se o unitate în diversitate ${ }^{34}$.

O serie de teologi apuseni văd sexualitatea ca pe un limbaj. Dialogul trupului şi al sufletului cauzează o realizare nemaiîntâlnită niciunde altundeva în natură. Este foarte uşor în condiţiile naturii umane căzute să devenim înrobiţi patimilor trupeşti, ce ar putea distruge orice comunicare. Aceiaşi teologi remarcă faptul că $a$ te indrăgosti este un lucru, iar a iubi este cu totul altceva, iar această putere a iubirii transformă viaţa. Olivier Clément, unul din teologii apuseni de care aminteam conchide că a iubi cu adevărat înseamnă a-l descoperi pe celălalt în identitatea sa specifica $\breve{a}^{35}$.

În ciuda îngrădirilor pe care căsătoria şi familia le-au creat în cadrul societăţii, caracterul exclusiv al iubirii conjugale pretinde un anumit grad de intimitate cu scopul de a crea o atmosferă plină de pace şi de iubire. Totuşi, convingerea noastră fundamentală este că iubirea nu se opune niciodată iubirii. Concepţia ortodoxă despre comuniunea sfinţilor susţine că la sfârşit ne vom iubi unii pe alţii în chip deplin şi în întregime, chiar dacă anumite iubiri au un caracter particular. Afirmaţia după care exprimarea fizică a iubirii este permisibilă doar într-un context sexual este cu totul greşită. Este adevărat că expresia genitală a iubirii este parte componentă a iubirii conjugale, în cadrul căreia un singur trup este esenţial şi reflectă unirea lui Hristos cu trupul Său, Biserica. Totuşi, în măsura în care fiinţele umane sunt corporale, trebuie să ne exprimăm sentimentele şi în chip fizic. Îmbrăţişările şi sărutările care există chiar şi în cea mai severă castitate, exprimă bucuria iubirii trupeşti care este pertinentă pentru cei care sunt mădulare ale trupului lui Hristos ${ }^{36}$.

\footnotetext{
${ }^{34}$ William Basil Zion, op. cit., p. 267.

${ }^{35}$ Olivier Clément, Life in the body, în „The Ecumenical Review”, vol. 33, nr. 3, 1981, p. 141.

${ }^{36}$ William Basil Zion, op. cit., p. 271.
} 


\section{Tratamentul tămăduitor al societăţii decăzute din punct de vedere moral}

Într-o lume lipsită de dragoste şi milă, societatea noastră insensibilă vinde puritatea feciorelnică a fiicelor ei pentru nesfârşita-i poftă de bani şi de putere. Dacă privim zecile de panouri publicitare sau privim la oricare dintre serialele televiziunilor comerciale sau doar aruncăm o privire în rafturile unui supermarket, înţelegem limpede care e produsul numărul unu al lumii moderne: sexul. Sexul nu se vinde însă singur, ci cu orice altceva, de la ţigări şi alcool până la mâncare pentru câini. După cum am văzut, adevărata iubire îşi regăseşte sensul în iubirea revelată de Dumnezeu, care este desăvârşită. Când Dumnezeu e înlăturat din mintea şi inima omului, adevărata iubire se pierde. Ceea ce rămâne e doar un veşmânt sub care omul îşi ascunde poftele sale trupeşti ${ }^{37}$. În condiţiile crizei spirituale a societăţii, mijloacele de informare în masă şi produsele aşa-zisei culturi de masă devin uneori instrumente de corupere morală, elogiind destrăbălarea sexuală, posibilitatea tuturor opţiunilor sexuale şi alte patimi păcătoase ${ }^{38}$.

Omul căzut, însă, a fost restaurat de către Hristos prin iconomia Sfintei Treimi. Pentru fiecare om în parte, mijloacele medicale pe care ascetica ortodoxă le pune la îndemână prin harul Duhului Sfânt, oferă posibilitatea însănătoşirii. Această însănătoşire a omului săvârşită de Hristos este dăruită potenţial fiecărei persoane prin Taine. Omul trebuie ca prin lucrarea sa, prin asceză, printr-o viaţă spirituală susţinută, să asimileze acest dar al lui Dumnezeu ${ }^{39}$.

Un prim pas în vindecarea acestei lumi ar fi lupta cu păcatul. O luptă, ca să reuşească, trebuie dusă în mod raţional; adică, să se

${ }^{37}$ John Marler şi Andrew Wermuth, Tinerii vremurilor de pe urmă. Ultima şi adevărata răzvrătire, trad. din limba engleză de Felix Truşcă, Bucureşti, Edit. Sophia, 2002, p. 28-29.

${ }^{38}$ Ioan I. Ică jr. și Germano Marani, Gândirea socială a Bisericii, Sibiu, Edit. Deisis, 2002, p. 234-235.

${ }^{39}$ Jean-Claude Larchet, Terapeutica bolilor spirituale, trad. de Marinela Bojin, Bucureşti, Edit. Sophia, 2001, p. 254-255. 
ştie de unde pleacă, încotro se îndreaptă şi care sunt mijloacele de care dispune. Totul porneşte de la ispită, iar în acest sens, pe lângă lupta dusă împotriva trupului şi a sângelui, trebuie să purtăm şi o luptă împotriva unor puteri spirituale, a căror inteligenţă uriaşă este pusă în serviciul răului ${ }^{40}$.

Văzul este simţul cel mai ager, iar Hristos a stigmatizat în mod deosebit concupiscenţa care începe din privire: Dar Eu vă spun că orişicine se uită la femeie ca s-o poftească a şi comis adulter cu ea în inima lui (Mt. 5, 28). Pipăitul este simţul cel mai primitiv şi cel mai periculos, dar şi celelalte simţuri trebuie înfrânate. Bătrânul Iosif Isihastul, cu bogata sa experienţă din Sfầntul Munte, zicea:

„Noi trebuie să fim atenţi asupra simţurilor, a celor lăuntrice şi a celor din afară. Căci fără această atenţie, mintea şi puterile sufletului se răspândesc în lucruri deşarte şi obişnuite - ca şi apa murdară ce curge pe drum. Nimeni nu se poate ridica spre înălţimi, dacă nu urăşte lucrurile pământeşti. Adesea, ne rugăm şi mintea noastră se împrăştie la lucrurile ce-i plac, este atrasă de obişnuit" ${ }^{41}$.

Pe lângă rugăciune, creatoare în viaţa religioasă, duhovnicească, pentru toţi, este Taina Spovedaniei - taina ridicării noastre şi a îndepărtării depline şi reale din noi a păcatelor noastre pe care le-am săvârşit şi prin care este readusă curăţia dintru început a sufletului nostru. Forţa curăţitoare a pocăinţei, pe lângă faptul că ne restituie în mod real curăţia sufletului pe care am pierdut-o, ne redă şi energia necesară pentru a învinge ispitele.

Iertării păcatelor în Sfânta Taină a Spovedaniei îi urmează iubirea deplină între mădularele Bisericii. Unirea aceasta deplină la care ne atrage Hristos prin prelungirea Trupului şi a Sângelui Său în trupul şi sângele nostru înseamnă şi o unire cu ceilalţi credincioşi, Euharistia fiind actul de sporire continuă a unităţii Bisericii. Eros-ul înduhovnicit ne ajută să creăm prietenia, care, la rândul ei, dă naştere

\footnotetext{
${ }^{40}$ Georges Habra, op. cit., p. 195.

${ }^{41}$ Dionyisios Tatsis, Cuvintele bătrânilor, trad. de Andrei Andreicuţ, Alba Iulia, Edit. Reîntregirea, 2004, p. 38.
} 
sentimentului de agape. Astfel, fiecare membru trăieşte şi simte viaţa celuilalt şi este responsabil pentru ea, ca şi cum ar fi viaţa lui proprie. Iubirea devine una autentică, impregnată de lumina lui Hristos. Este o iubire în Hristos şi nu în afara Lui. Este o iubire care are ca model iubirea Sfintei Treimi. Deşi trăită de om, iubirea aceasta nu are nimic pătimaş în ea, pentru că izvorăşte din Hristos ${ }^{42}$.

De o importanţă majoră în lumea seculară robită erotismului este Taina Cununiei. Dacă tinerii ar cunoaşte importanţa şi semnificaţia acestei Taine, cu siguranţă lumea ar fi mai puţin stăpânită de păcat. Intâi de toate, prin această Taină se realizează unirea cu Hristos după Har şi identitatea umanităţii ${ }^{43}$. Am afirmat deja că prin Taina Nunţii, în Hristos şi în Biserică, cei doi devin un singur trup, iar erosul natural e transfigurat şi sfinţit în noua existenţă umană, fiind, de asemenea, şi leac împotriva desfrânării.

Prin sfintele Taine ale Bisericii se spiritualizează, aşadar, viaţa intimă a omului, care o tămăduiesc de orice boală şi neputinţă.

Un alt mijloc prin care Hristos se poate apropia de omul din societatea contemporană este exemplul şi propovăduirea celor ce au o viaţă spirituală aleasă, întrucât credinţa este din auzire, iar auzirea este prin cuvântul lui Hristos. Filotei, Bătrânul din Paros, zicea: Adevărata fericire nu constă din demnităţi, nici din odihna trupului. Adevărata fericire este virtutea. Cei ce luptă pentru a dobândi virtuţile şi pun în practică poruncile lui Dumnezeu sunt cu adevărat fericiţi ${ }^{44}$. La fel de frumos, Bătrânul Ioil ne îndemna să nu visăm sau să vorbim în aer, ci să gândim şi să uzăm de raţiunea noastră ! Să zburăm, dar, în acelaşi timp, să avem şi picioarele pe pământ ${ }^{45}$.

Pentru a comunica credinţa astăzi, trebuie să dăm permanent prioritate exprimării dragostei într-o manieră nouă. Mai mult decât claritate conceptuală, avem nevoie să luăm contact cu vieţi

\footnotetext{
${ }^{42}$ Sorin Emanuel Bugner, Viaţa intimă a omului şi provocările postmoderniste asupra acesteia, Alba Iulia, Edit. Reîntregirea, 2009, p. 274.

${ }^{43}$ Ibidem, p. 278.

${ }^{44}$ Dionyisios Tatsis, op. cit, p. 82

${ }^{45}$ Ibidem, p. 83.
} 
convertite, cu existenţe transformate de experienţa întâlnirii cu Dumnezeu.

Totul gravitează în jurul iubirii. Ea ne învaţă cum să ducem o viaţă virtuoasă într-o lume a desfrâului, iar puterea acesteia de a depăşi toate limitele este un dar al Duhului Sfânt. Iubirea este chiar sfinţenia, o sfinţenie întemeiată pe purificarea iubirii, precum şi a tuturor plăcerilor senzuale. Ajunşi aici, împărtăşirea Duhului Sfânt ne pregăteşte pentru ospăţul tainic, unde iubirea va fi desăvârşită şi nu va mai cunoaşte nicio piedică şi nici vreun sfârşit, căci Dumnezeu va fi totul în toate ${ }^{46}$.

\section{Concluzii}

Fără îndoială, vremurile pe care le trăim sunt marcate de perversitate şi obscenitate. Mass-media încurajează această tendinţă, de cele mai multe ori oferind idei oamenilor imorali care au ajuns să catalogheze anormalul, normal. Chiar şi cunoştinţele în domeniul acesta sunt tot mai numeroase, iar lucrurile nu se opresc aici, întrucât avem un drum lung de parcurs în ceea ce priveşte justificarea vederilor noastre metafizice şi ştiinţifice despre orientarea sexuală şi dorinţele sexuale.

În societatea contemporană, prin urmare, sarcina creştinului care doreşte să-şi păstreze curăţia şi să trăiască moral, după voia lui Dumnezeu, pare a fi foarte dificilă. Ea este cu atât mai greu de îndeplinit, cu cât lumea modernă, în totalitatea ei, a atins un nivel de pervertire pe care nu 1-a mai atins vreodată. Însă, urmând sfaturile şi exemplele sfinţilor care s-au tămăduit de bolile păcatelor, urcând treaptă cu treaptă pe scara virtuţilor, prin străduinţă şi osteneală, cu ajutorul şi harul lui Dumnezeu, omul contemporan se poate vindeca de această patimă, ridicându-se la înălţimea curăţiei şi a sfinţeniei la care este chemat de Creatorul său.

Am subliniat caracterul grav al desfrâului apărut în urma pervertirii instinctului primar sădit în om. Totuşi, legătura dintre

${ }^{46}$ William Basil Zion, op. cit., p. 296-297. 
bărbat şi femeie este binecuvântată de Dumnezeu în Taina Sfintei Cununii, în care, prin iubire, cei doi devin un singur trup. Vindecarea de patima desfrânării presupune paza inimii şi a minţii, prin trezvie duhovnicească şi discernământ spiritual, prin respingerea gândurilor, a amintirilor şi a fanteziilor de această natură şi prin constanta lectură duhovnicească şi ascultarea de un părinte duhovnicesc iscusit. Totodată, de un real folos în tămăduirea de această patimă cumplită sunt paza trupului şi a simţurilor, fuga de ispită şi de ocazia la păcat, fecioria sau căsătoria, precum şi disciplina conjugală.

Şi pentru că Dumnezeu este iertător şi îndelung-Milostiv, nea oferit posibilitatea îndreptării, creându-ne prin Sfintele Taine şi alte mijloace adiacente cadrul necesar pentru a îndrepta anumite lucruri în această societate şi a trăi în ea o viaţă morală autentică. Iubirea curată este cea care prelungeşte viaţa lui Hristos în existenţa noastră pământească, întrucât în fiecare trup curat se ridică un templu sfânt al lui Dumnezeu, în sensul în care un tânăr neprihănit e un altar pe care Hristos binevoieşte să se aducă pe Sine jertfă bineplăcută Tatălui.

\section{Bibliografie}

1. Andreicuţ, Andrei, Mai putem trăi frumos? Pledoarie pentru o viaţă morală curată, Cluj-Napoca, Edit. Renaşterea, 2012.

2. Basil Zion, William, Eros şi Transfigurare, trad. de Ioan Ovidiu Bobăilă, Alba Iulia, Edit. Reîntregirii, 2001.

3. Brownson, James V., Bible, gender, sexuality: a critical engagement, The Kirby Laing Institute for Christian Ethics, 2014, p. 35

4. Bugner, Sorin Emanuel, Viaţa intimă a omului şi provocările postmoderniste asupra acesteia, Alba Iulia, Edit. Reîntregirea, 2009.

5. Clément, Olivier, Life in the body, în „The Ecumenical Review”, vol. 33, nr. 3, 1981.

6. Dahl, Darren W., Sengupta, Jaideep, Vohs, Kathleen D., Sex in Advertising: Gender Differences and the Role of Relationship Commitment, în „Journal of Consumer Research”, vol. 36, Nr. 2, August 2009.

7. Elchaninov, Alexander, Credinţa vine din iubire, trad. de Boris Buzilă, Bucureşti, Edit. Sophia, 2005. 
8. Evdokimov, Paul, Taina iubirii. Sfinţenia unirii conjugale în lumina tradiţiei ortodoxe, trad. de Gabriela Moldoveanu, Bucureşti, Edit. Christiana, 1994.

9. Habra, Georges, Iubire şi senzualitate, trad. de Dora Mezdrea, Bucureşti, Edit. Anastasia, 1994.

10. Hill, Zelee E., Cleland, John, Ali, Mohamed M., Religious Affiliation and Extramarital Sex among Men in Brazil, în „International Family Planning Perspectives", vol. 30, Nr. 1, Martie 2004.

11. Ică, Ioan I. jr., Marani, Germano, Gândirea socială a Bisericii, Sibiu, Edit. Deisis, 2002.

12. Larchet, Jean-Claude, Terapeutica bolilor spirituale, trad. de Marinela Bojin, Bucureşti, Editura Sophia, 2001.

13. Mantzaridis, Georgios, Morala creştină, trad. de Cornel Constantin Coman, București, Edit. Bizantină, 2006.

14. Marler, John, Wermuth, Andrew, Tinerii vremurilor de pe urmă. Ultima şi adevărata răzvrătire, trad. din limba engleză de Felix Truşcă, București, Edit. Sophia, 2002.

15. Mladin, Nicolae, Bucevschi, Orest, Pavel, Constantin, Zăgrean, Ioan, Teologia Morală Ortodoxă, manual pentru Facultăţile de Teologie, vol. I, Alba Iulia, Edit. Reîntregirea, 2003.

16. Moldovan, Ilie, Adolescenţa, preludiu la poemul iubirii curate, ediţia a treia, Alba Iulia, Edit. Reîntregirea, 2014.

17. Moussa, Bishop, Youth and pure love, în Hanna, Fr. Markos R., Moral Issues: The Church's View Point on Contemporary Issues, United States of America, Xlibris Corporation, 2012.

18. Pop, Irineu, Curs de Bioetică, Cluj-Napoca, Edit. Renaşterea, 2005.

19. Sfântul Grigorie de Nyssa, Expositio in Ecclesiastem Salomonis, Migne PG 44, col. 625-754.

20. Sfântul Ioan Gură de Aur, Comentariile sau explicarea Epistolei către Romani, Omilia V, trad. de Theodosie Athanasiu, Bucureşti, Atelierele grafice Socec \& Co, 1906.

21. Sfântul Ioan Gură de Aur, Despre feciorie, trad. de Dumitru Fecioru, Bucureşti, Edit. Institutului Biblic şi de Misiune al Bisericii Ortodoxe Române, 2001.

22. Sfântul Vasile cel Mare, Omilii la Hexaemeron, în „Scrieri”, partea întâi, traducere, introducere, indici şi note de Dumitru Fecioru, col. „Părinţi şi Scriitori Bisericeşti”, vol. 17, Bucureşti, Edit. Institutului Biblic şi de Misiune al Bisericii Ortodoxe Române, 1986.

23. Sfầntul Vasile cel Mare, Omilia a III-a, în „Omilii şi cuvântări”, traducere din limba greacă şi introducere de Dumitru Fecioru, text 
revăzut şi notă asupra ediţiei de Dumitru Fecioru, Constantin Georgescu şi Alexandru Mihăilă, col. „Părinţi şi Scriitori Bisericeşti”, serie nouă, vol. 1, Bucureşti, Edit. Basilica a Patriarhiei Române, 2009.

24. Stăniloae, Dumitru, Sfânta Treime sau la început a fost iubirea, Bucureşti, Edit. Institutului Biblic şi de Misiune al Bisericii Ortodoxe Române, 2005.

25. Stein, Edward, The Mismeasure of Desire: The Science, Theory and Ethics of Sexual Orientation, New York, Oxford University Press, 1999.

26. Tatsis, Dionyisios, Cuvintele bătrânilor, trad. de Andrei Andreicuţ, Alba Iulia, Edit. Reîntregirea, 2004.

27. Tia, Teofil, Culisele psihice ale sexualităţii, Alba Iulia, Edit. Reîntregirea, 2010-2011.

28. Tia, Teofil, Un (im)posibil dialog duhovnicesc al erei post-moderne, Alba Iulia, Edit. Reîntregirea, 2010.

29. Zenkovsky, Vasily Vasilyevich, Convorbiri cu tinerii despre sexualitate, trad. de Dimitrie Balaur, Bucureşti, Edit. Bizantină, 2006. 